\title{
鎮江市内江の流動計算のための 長江水理条件の導出 \\ REASONABLE DERIVATION OF HYDRAULIC CONDITION FOR CFD IN Zhenjiang CITY
}

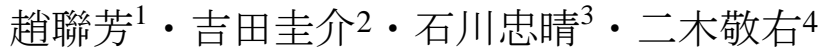 \\ Lianfan ZHAO, Keisuke YOSHIDA, Tadaharu ISHIKAWA and Keisuke FUTAGI \\ 1 非会員 修士（工） 東京工業大学大学院（†226-8502 横浜市緑区長津田4259番地） \\ 2正会員 博士（工） 東京工業大学大学院 産学官連携研究員（ \\ 3フェロー会員 工博 東京工業大学大学院 教授（广226-8502 横浜市緑区長津田4259番地） \\ 4学生会員 学士（工） 東京工業大学大学院 修士課程（下226-8502 横浜市緑区長津田4259番地）
}

\begin{abstract}
It is with much frequency that we can't get enough field data to define boundary conditions for hydraulic calculations especially in developing countries. The authors faced this kind of problem in a research on water exchange of the Neijiang, a tideland located in the lower reach of the Changjiang in China. This paper presents a process to estimate the boundary conditions for quasi-3D numerical simulation from limited available data: The water exchange of the Neijiang is controlled by the flow rate and the water stage of Changjiang which are highly changed in a day by tidal waves going up from the river mouth. In this study, 1-D unsteady flow model was constructed and calibrated by using the monthly flow rate at a far upstream station free from the tidal effect and the hourly data of tidal level at the river mouth, and the flow rate and the water level near the tideland necessary for the quasi-3D calculation were estimated. The results were checked by the water level data at one of the mouths of the Neijiang.
\end{abstract}

Key Words: reasonable numerical method, making the hydraulic condition, combined numerical method

\section{1. はじめに}

我が国の水理技術者・研究者が発展途上国の事業に携 わる機会が増えてきている，その際に最も困難なことは 現地データの入手である. 国内では種々の現地データが 豊富で且つ入手しや寸く，このことを前提として手法が 組み立てられる傾向にある. しかしデータの乏しい発展 途上国では，何らかの工夫をしないとそれらの手法を活 かせないことも多い.

例えば,詳細な水理シミュレーションを行う場合には, それなりに詳細な地形, 流量, 水位などの条件を設定す る必要がある. また水質計算を行う場合には流入水の水 質のほかに底質状態などの条件を設定する必要がある. それらのデータが入手できない場合には，入手できるデ 一タから計算に必要な変数の值を推測する必要が生じる.

筆者らは，中国の長江河口から約 $300 \mathrm{~km}$ 上流にある内 江干潟の水交換特性に関する数值シミュレーションを行 うために，その付近の長江の流量と水位の時間データを 入手する必要があった. 内江干潟は長江の感潮域にある ため, 河口から遡上寸る潮汐波の影響により, 流量と水
位が一日の中で大きく変動するからである.

しかし，中国では時間観測データが少なく，また有料 で且つ高価なため, 長期間の時間データの入手は困難な 場合が多い.さらに政治・軍事上の理由などもあって, 詳細な地形データの入手は容易でない，そこで本研究で は, 数值シミュレーションの境界条件として必要な流量 と水位の時系列を, 入手可能なデータを組み合わせて推 定することとした.

このような作業は, 対象とする現象の性質や現地デー タの入手状況に合わせて個別に工夫寸ることになるから， 普遍的な手法は存在しないといえる. しかし, それら個 別の検討結果の集積によるノー・八ウの体系化が，今後 の海外事業の展開を円滑にする上で特に重要であると考 え報告するものである.

\section{2. 対象フィールドの概要}

鎮江市は長江河口から約 $300 \mathrm{~km}$ 上流の右岸にあり, 三 国志演義や白蛇伝説で有名な町である。長江の主流が北 に移動したため, 旧流路が内江として取り残された（図 
表-1 入手できたデータ

\begin{tabular}{|c|c|c|c|}
\hline 種類 & 場所 & 時期 & 出所 \\
\hline 流量 & 大通(河口から約600km) & 2001年,2003年,2004年 & 大通水利基地, Internet \\
\hline \multirow{3}{*}{ 水位 } & 河口 & 2003年 & TIDE TABLES 2003 国家海洋信息中心編 \\
\hline & 内江入口 & 2004年5月～2005年5月 & 鎮江市水利局 \\
\hline & 内江内部 & 1998年～2004年 & 鎮江市水利局 \\
\hline \multirow{4}{*}{ 地形 } & 内江 & 2005年 & 鎮江市水利局 \\
\hline & 対象領域 & 1998年 & 江蘇省水利局 \\
\hline & 河口水位観測所 & 2003年 & TIDE TABLES 2003 国家海洋信息中心編 \\
\hline & 鎮江，江陰 & 2005年 & 江蘇省水利局 \\
\hline
\end{tabular}

-1）。鎮江市は内江を自然水辺公園として整備しようと しているが，閉鎖性が強く水質の悪化が予想される. そ こで長江との水交換可能量の推定が検討課題となった.

鎮江市付近は長江の感潮域にあたり，後述するように $1 \mathrm{~m}$ 程度の干満がある. 内江は上流と下流の2箇所で長江 に接続しているため，上げ潮時には下流から，下げ潮時 には上流からの流入が期待される. しかし，長江の水位 情報が十分公開されていないために，水理計算ができな い状態にあった. そこで, 本研究では入手可能であった 情報を基に, 内江の水理計算に必要なデータを作成した.

\section{3. 入手できたデータ}

一般に中国では2つの理由で水理データの入手が難し い. 計測そのものが行なわれていない場合と，データが 公開されていない場合である. 非公開といっても機密と いうわけではない，中国では，デー夕は取得した人もし くは組織のものであり，一般的には有料（それもかなり 高額) である. ただし人のつながりにより無償ないし廉 価になることもある.

本研究の過程で入手できたデータを表-1に示す。この うちの流量については，2004年は数值を入手できたが， 2001年と2003年はinternet上にあるグラフから值を読み 取った. 水位については図-1にうで示寸地点での満潮・

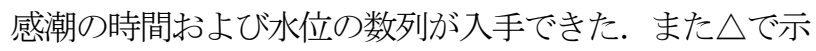
寸地点では満潮・感潮の水位のみの数列が入手できた.

\section{4. データ作成方針}

内江干潟は, 約 $20 \mathrm{~km}$ 離れた2箇所で長江に接続してお り，潮汐波の遡上に伴い上下流で水位が逆転することも ある. しかし両地点の水位時系列が完備していないこと から, 内江のみを切り出して水位計算を行うことはでき ない，そこで本研究では，図-1に示寸区間の長江を含め て準三次元計算を行うこととした，そのためには，計算 の境界条件となる上流端流量と下流端水位が, 潮汐波の 遡上現象に合致するよう合理的に導出されなければな らない，そこで本研究では，一次元不定流計算により，

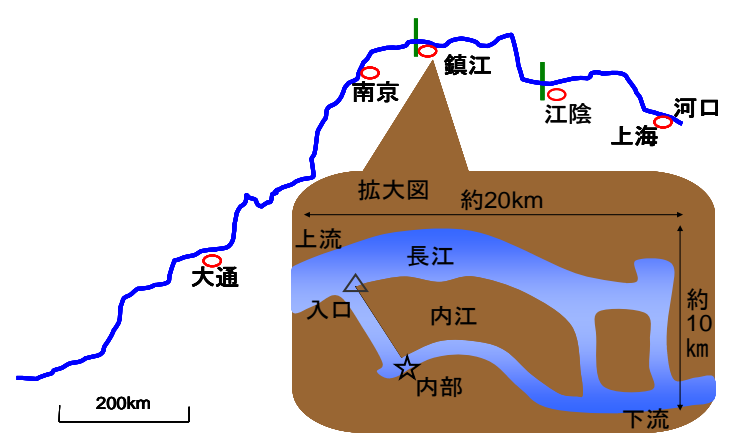

図-1＼cjkstart長江下流域と鎮江市内江の概要

長江河口からの潮汐波遡上特性を検討することにした.

しかし, 不定流計算モデルを組み立てるための情報が 極度に不足していた. 図-1の区間の地形データについて は, 鎮江市の水環境整備projectに参加していた第一著者 の所属機関が保有していたが，上流および下流の河道地 形に関する情報はほとんどなかった. また表-1に示した ように, 流量と水位に関するデータは断片的であり整合 性を欠いている. そこで本研究では, 内江の流動を支配 する最大の要因である「長江における潮汐波の遡上」を 内江付近で経験的に再現できる「仮想的河道」を想定し， 少ない観測情報を有効利用し, 1次元不定流計算を行う.

この計算に必要な情報としては, (1) 河道断面形状,

(2) 河床勾配 $i$, (3) 上流端の流量時系列 $Q(t)$, (4) 下流端 での潮位時系列 $\mathrm{Ho}(t)$, (5) 平均水深 $h$, (6) 粗度係数 $n$ で あるが，それらを以下のように段階的に求めた. その結 果を1次元河道モデルの第一近似值として計算を行い, 観測值と比較した後, 観測值に近づくようにパラメータ の調整を行った.

（1) 河道断面形状に関する情報は，図-1に緑の実線で 示すように, 内江と江陰で1断面のデータが得られ ている. そこで, 本研究ではこの横断形状を基に して台形型の横断形状を計算で利用した.

(2) 河床勾配 $i$ は内江と長江河口の水位差加, 等流を 仮定して推定した. また, この際, 中国科学院地 理研究所が1985年に発行した測量レポート吕のデ ータを参考にした。 


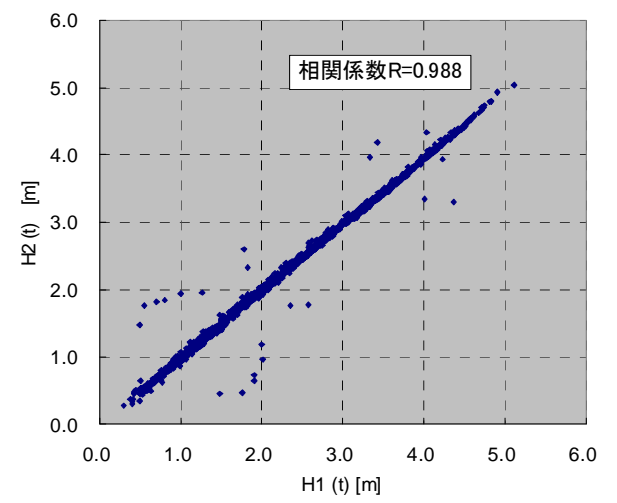

図-2 水位変動の相関

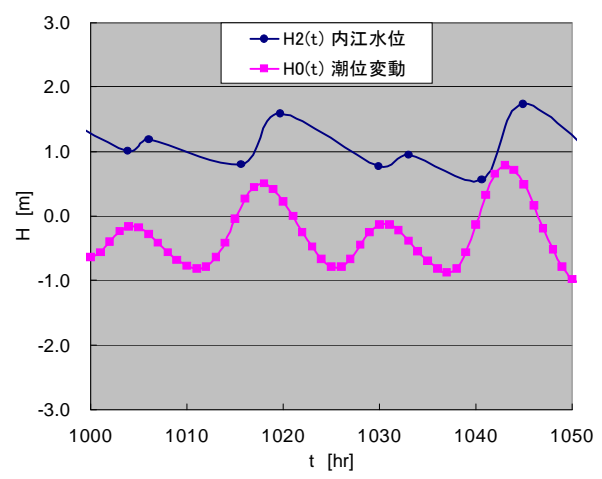

図-3 水位と潮位の変動の時系列

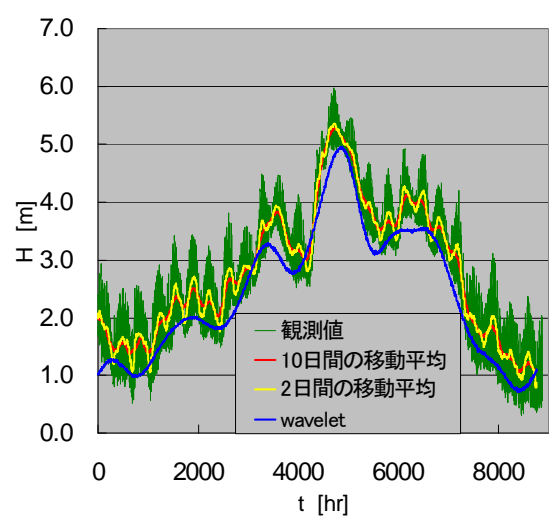

図-4 水位変動の時系列

(3) 内江から $300 \mathrm{~km}$ 上流の大通には流量観測所があり， ここでは月平均の流量值(2001年，2003年および 2004年の各々 1 年分)のデータがある. そこで，この 観測所の月毎の流量データを基にしてH-Q式から1 次元不定流計算に利用寸る流量の時系列データを 作成した. しかし， $H$-Q式の作成にあたり，水位 $H$ は大通で観測されていないため，代わりに内江で の観測值を利用した。この際，大通から内江まで の間で，長江に流入する大河が存在しないことを 確認した．また，内江入口では2004年5月〜2005年 5月までしか水位H1(t) のデータが観測されていな いため（表-1参照），その代わりに内江内部で観 測された水位 $H 2(t)$ のデータと内江入口の水位 $H 1(t)$ の相関関係を確認して，H2(t) のデータを
$H-Q$ 式作成の上で利用した. さらに，H2(t) のデー 夕は潮汐変動を含むため, 以下で示すように, wavelet解析と移動平均により水位 $H 2(t)$ の変動の うち, 低周波成分のみを取り出し, $H-Q$ 式作成の段 階で利用した。

(4) 下流端での潮位変動Ho(t) は2003年の1年分のみ観 測されている. 他の年の変動は潮汐の調和解析に より求めた.この際, 2003年の1年分の観測潮位の データから, 調和解析に必要な数十個のパラメー タを決定した。

(5) 平均水深 $h$ は以下のように求める. 前述のように鎮 江市内江は感潮域であり, 長江河口の潮位変動が 時間差をもって内江に到達する. 2003年には河口 の潮位変動 $H o(t)$, 内江内部の水位変動 $H 2(t)$ および 大通での月平均流量Qの各々の観測值が得られて いる. そこで，水面波を個別に追跡することによ り，時間差を概算した．これを月ごとに平均し， 水面波の波速が長波の波速と長江の流速の和に等 しくなるように平均的な水深を求めた.

(6) 粗度係数 $n$ は上記で求めた流量, 時間平均的な縦断 水位勾配および河幅を利用して, Manning式から推 定值を得た.

\section{5. データの作成と解析}

\section{（1）流量の時系列データQ(t)の作成}

a) 内江の入口水位 $H 1(t)$ と内部水位 $H 2(t)$ の相関

内江の入口水位 $H 1(t)$ の観測所は長江に面しているた め, この水位変動は長江の流動形式に従うものと考えら れるが, 内江内部 (図-1参照) の水位変動 $H 2(t)$ の応答 がH1(t) と同様かどうかをここでは確認する. なお，両 データの観測時間差は10分程度未満であり, 両水位デー タはほぼ同時刻に観測されているものと考える. 図-2に は両者の相関と相関係数を併示した. なお, 水位は黄海 基準面(青島)を基準としており, 以後もこの基準を用い ることにする. これより, 内江内部の水位変動 $H 2(t)$ はほ ぼH1(t) と同様であり, $H 2(t)$ を $H-Q$ 式作成時のデータと して利用できることがわかる。

\section{b) 内江の水位 $H 2(t)$ の時系列解析}

図-3には2003年の水位変動 $H 2(t)$ と潮位変動 $H o(t)$ の 時系列の一例を示した. $H 2(t)$ の時間変動を観察すると, 時間軸で波形がほぼ対称であった水面変動が上流への 伝播時に歪み変形を生じていることがわかる，一般に， 感潮域の水位変動は流量と潮位の両者の影響を受ける ため, このH2(t) の時系列データをそのまま利用して, $H-Q$ 式を作成することはできない，そこで，本研究では 感潮域を外れた内江からさらに $300 \mathrm{~km}$ 上流域の大通で 観測された流量 $Q$ と, 内江で観測された水位変動 $H 2(t)$ の低周波成分との間でH-Qの回帰式を作成することと した. 


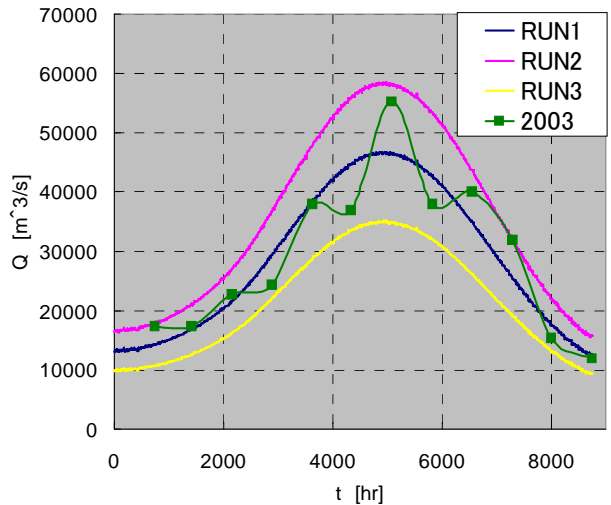

図-5 流量の時系列

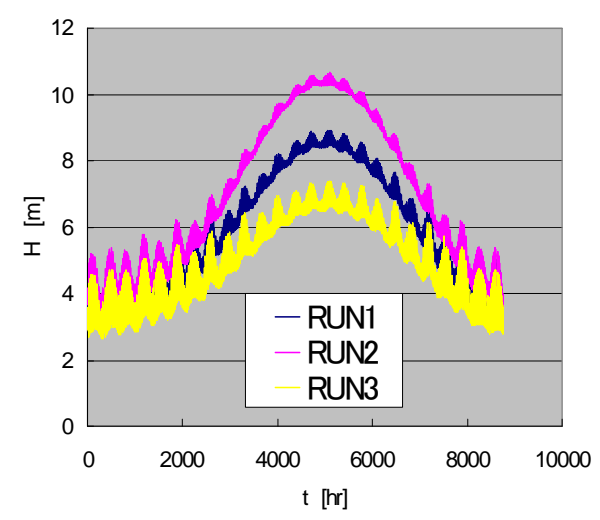

図-6 水位の時系列

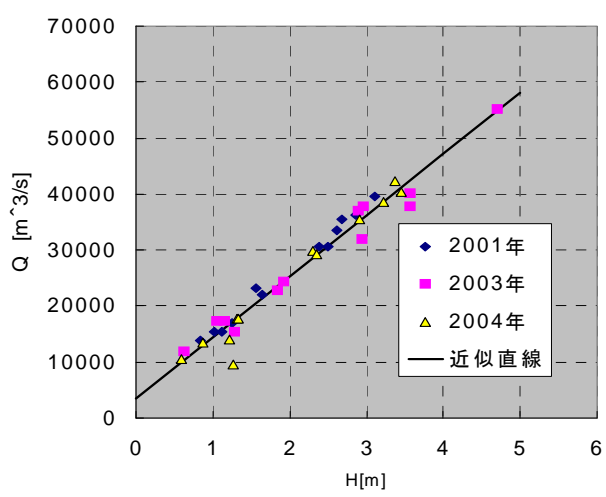

図-7＼cjkstart水位Hと流量のの相関

本研究では水位変動における潮位と流量の影響を分 離するために, i) Wavelet解析による周波数分離, および ii) 移動平均による高周波数変動の除去の 2 通りの方法 を試みた. Wavelet解析はフーリエ解析と異なり，同一 周波数帯の変動の時間的な変化を捉えることができる 点で優れている. 本研究ではwavelet解析に利用した関数 として，Daubechieの正規直交マザーウェーブレット²)を 用いた. 図-4には, オリジナルの水位変動 $H 2(t) に$ 対して, 2 日間および10日間の移動平均を施した際の変動 $H 2_{2 \text { days }}(t), H 2_{10 \text { days }}(t)$ と, Wavelet解析により大潮・小潮を 含んだ20日周期以下の水位変動を除去した変動成分 $H 2_{\text {wave }}(t)$ を併示した。 これより, Wavelet解析では移動平 均に比べて生データの滑らかな変動值を合理的に得る ことが出来ると考えられる.
さらに，もう一つの試みとして，移動平均により潮汐 波の影響を除去する方法では, 3通りの数值実験を行い， それぞれからH-Q関係を推定してみた. 寸なわち，図-4 に示したグラフから, 単純な移動平均の他に, 満潮位を 結ぶ線と干潮位を結ぶ線の活用も考えられる.ここでの $H-Q$ 関係の検討は, 特に干潮位の線は比較的変動が小さ いことから, 流量の季節変化に対応していることが期待 される. そこで，観測潮位を与えた場合に流量の系統的 な変化に対して同様の議論が可能なのかを検討するた めに，3通りの数值実験を行った. この数值実験では仮 想的な矩形断面水路における1次元不定流計算を行った. なお，流量Qを与える断面は潮位 $H_{o}(t)$ を与える河口か ら600km上流とし，議論の対象とする水位変動は河口か ら300km上流の断面とした。図-5にはこの数值実験

（Run1〜Run3）で利用した流量の時系列と2003年の大 通での月平均流量を併示した. 図中, 流量波形及び流量 值の最小值 $Q_{\min }$ と最大值 $Q_{\max }$ は長江での観測流量の最小 值，最大值と同程度の值に設定した．潮位は各Runで同 一とし, 波形及び值は2003年の観測值をそのまま利用し た. 図-6には各Runでの水位の計算結果を示した. いず れの場合も, 先ほどの予想に合致するように, 干潮位の みを結んだ包絡線は滑らかであることがわかる。

Wavelet解析と比較して，この方法は特別な知識が必要 でなく, 誰でも可能であるため本研究では以下の $H-Q$ 式 作成時には, このようにして得られた水位 $H 2_{\text {Low }}(t)$ を利用 した.

\section{c） H-Q式の作成}

図一ーには上に述べた方法で得られた $H 2_{\text {Low }}(t)$ を月平均 した水位 $H_{m}$ に対して, 各月の平均流量 $Q_{m}$ との相関を示 した. 図中には2001年, 2003年および2004年の結果を併 示した.これから，各年間でデータのばらつき度合いは 少なく，ひとつの回帰式でほぼ合理的に $H-Q$ 式を作成で きることがわかる.

\section{（2）潮位の時系列データ $H o(t)$ の作成 — 調和解析結果}

潮汐の調和分解には昔からDarwinの方法, Tा法など 様々な方法が用いられている. ここでは気象庁などで標 準的に実施されている潮汐の天文潮位予測法に倣い，調 和定数に60個の分潮を用いた調和解析を行って, 潮位の 時系列データの作成を行う. 本研究では調和解析には次 式を用いだ3.

$$
\eta=\sum_{i=1}^{N} f_{i} H_{i} \cos \left(V_{0 i}+u_{i}+\omega_{i} t-k_{i}\right)+Z_{0}
$$

ここで，Nは分潮の個数（本研究では60）， $f_{i}$ は太陰の 昇交点の黄径によって変化する係数， $H_{i}$ は分潮の振幅， $V_{0 i}$ は分潮の引数で時間と共に変化する量で, 添字の0は グリニッジ天文台の值を示寸． $u_{i}$ は分潮の引数で時間に 依存する量, $\omega_{i}$ は分潮の角速度, $t$ は現地標準時, $k_{i}$ は分 潮の遅角であり，Z。は基本水準面 (黄海基淮面)である. 


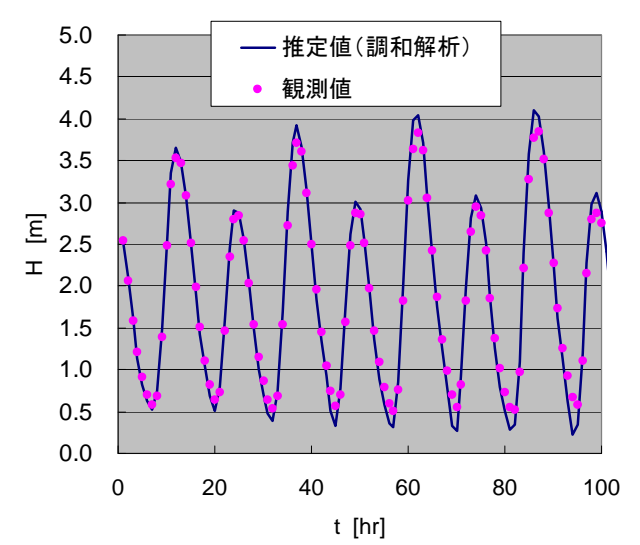

図-8＼cjkstart調和解析結果

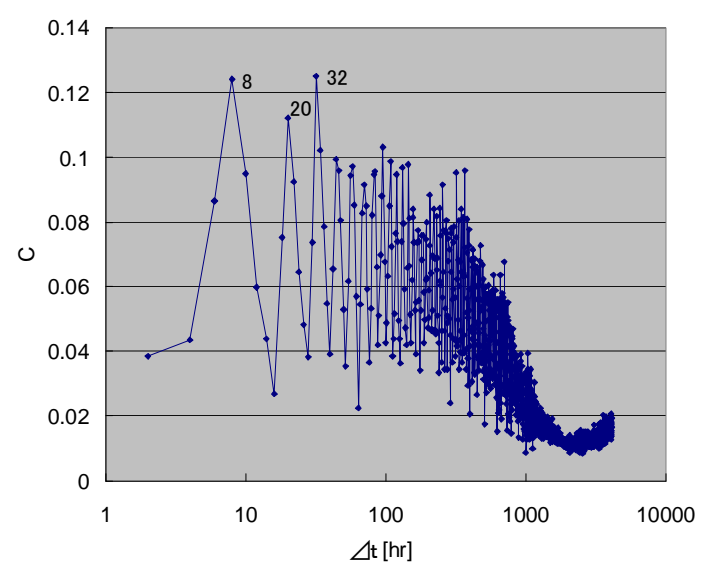

図-9 遅れ時間 $\Delta t[h r]$ と相互相関係数 $C_{\text {thrt }}$ (図中，係数はCで表示した）

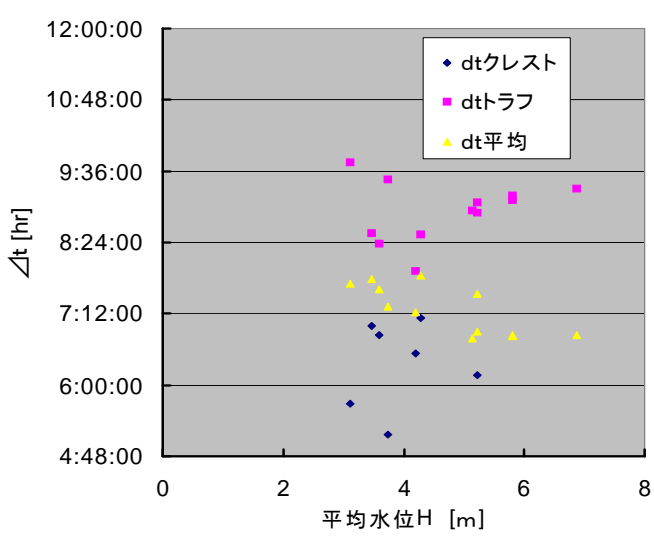

図-10 平均水位 $H$ と遅れ時間 $\Delta t[\mathrm{hr}]$ との関係

本研究では60個の分潮に対するパラメータ（調和定 数）の情報が現地データから得られなかったため, 2003 年に1時間毎に観測された1年分の潮位変動を用いて, 調 和定数を求めた. 本研究ではこれら定数の決定に際して 最小自乗法を用い, 行列解法にはガウスの消去法を用い た. 図-8には2003年の観測結果と調和解析の結果を併示 した. これより，観測結果と解析結果を比較すると，潮 汐の位相および振幅がほぼ一致する様子がわかる. そこ で, 本研究ではこの結果で得られた調和定数を用いて, 他の年度の潮位変動值を求めることとした.

\section{（3）河道の平均水深 $h$ の推定}

平均水深の決定には次式を用いる.

$$
\frac{L}{\Delta t}=C \cong-\frac{Q}{B \cdot h}+\sqrt{g h}
$$

ここで，L (=300[km]） は内江〜長江河口の縦断距離, $\Delta t$ は水面波の到達時間, $C$ は水面波の波速, $Q$ は観測流 量, Bは平均的な長江の川幅, $g$ は重力加速度である. 上式では長波の波速を仮定している.

このとき, 潮位変動が河口から長江河道を上流方向に 遡上していき, 内江に到達するのに必要な時間 $\Delta t$ を求 める必要がある.この時間を以下では遅れ時間と呼ぶ. この遅れ時間 $\Delta t か ゙$ 長波の波速の逆数にほぼ比例すると 考えると, 年間を通じて長江の水深が変化するのに応じ て $\Delta t か ゙$ 応答することが予測される，そこで，まず1年間 の河口の潮位変動 $H o(t)$ と内江の水位変動 $H 2(t)$ との間 での平均的な $\Delta t$ を概算し，その後，その值を参考にして 各月毎の平均的な $\Delta t$ 目視により調べることとした.

図-9には2003年の観測潮位 $H o(t)$ と内江水位 $H 2(t)$, 両 者の変動間での相互相関係数 $C_{\mathrm{HOH} 2}$ をFFTで解析した結 果を示した. 遅れ時間 $\Delta t=8[\mathrm{hr}]$ 周辺で相互相関係数 $C_{\mathrm{HoH} 2}$ は最大值を示寸ことがわかる。

一方，図-10には2003年の1年間の水面波形に対して， 各月毎の平均的な遅れ時間 $\Delta t$ を目視により読み取った 結果を, 波のクレスト，トラフおよびそれらの平均值に 分けて併示した. この結果より, $\Delta t$ は各月の平均水位の 逆数に比例して，6時間～9時間程度の值を有することが わかり, 先ほどのフーリ工解析の結果を支持するものと なった. そこで, 式(1)に各月の $\Delta t$ を与え, 反復計算から 各月の平均水深hを求めた. この結果を図-11に示寸. 図 から, 平均水深の平方根は遅れ時間の逆数に比例するこ とがわかる. そのため, 時間軸で局所的に考察すると, 水面波の到達時間は長波の波速によりほぼ記述できる ことがわかる. また, 式(2)の右辺おいて第1項と第2項の オーダーを比較すると，第2項は大きく卓越しており， 以下では内江の水位変動を支配する量として水深の年 間の平均值 $(=15[\mathrm{~m}])$ を第一次近似值として利用するこ ととした. なお,この結果は後で示寸横断面の測量值(図 -12) から得られる平均的な河道の水深とほぼ一致する.

\section{（4）1次元不定流計算によるデータの作成}

本研究で用いた一次元不定流計算の基礎方程式は以 下である。

$$
\begin{aligned}
& \frac{\partial A}{\partial t}+\frac{\partial Q}{\partial x}=0 \\
& \frac{\partial Q}{\partial t}+\frac{\partial U Q}{\partial x}=-g A \frac{\partial H}{\partial x}-g A \frac{\tau}{\rho g R}+\frac{\partial}{\partial x}\left(\kappa \frac{\partial U}{\partial x} A\right)
\end{aligned}
$$

ここで， $\quad A$ は断面積 $\left[\mathrm{m}^{2}\right] ， \quad Q$ は流量 $\left[\mathrm{m}^{3} / \mathrm{s}\right], \quad U=Q / A$ は断 面平均流速 $[\mathrm{m} / \mathrm{s}], H$ は水位 $[\mathrm{m}], \rho$ は水の密度 $\left[\mathrm{kg} / \mathrm{m}^{3}\right], \tau$ 


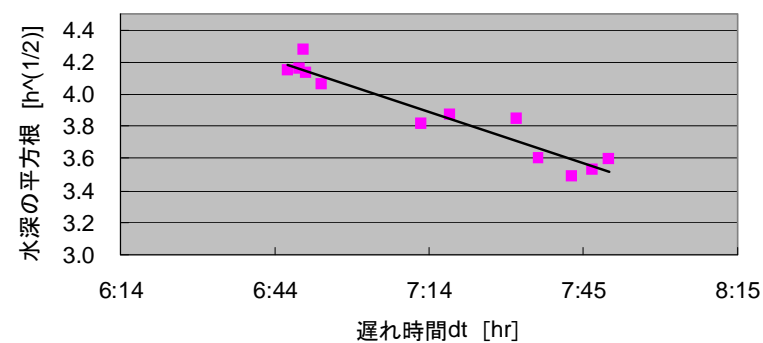

図-11 遅れ時間と水深の平方根

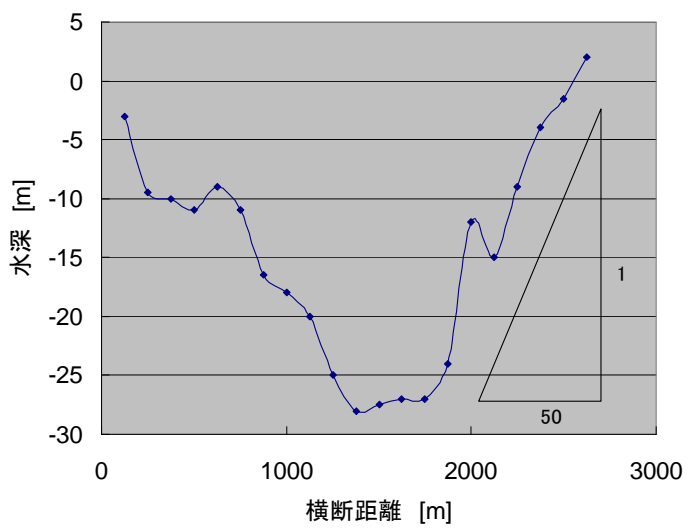

図-12 横断地形（測量データ）

は河床のせん断応力 $\left[\mathrm{kg} /\left(\mathrm{m} \cdot \mathrm{s}^{2}\right)\right], g$ は重力加速度 $\left[\mathrm{m} / \mathrm{s}^{2}\right], R$ は径深, $\kappa$ は渦粘性係数 $\left[\mathrm{m}^{2} / \mathrm{s}\right]$ である. ここで, 式(4)の右 辺第3項はReynolds応力を示し, $\tau$ はManning式 $(\tau=f U|U|$, 摩擦係数 $f=g n^{2} / h^{1 / 3}$ であり, $n$ はManning係数) で算定した. 次に, 本計算では単断面一様水路を用いた. 河道のモ デルを決めるための情報として, 本研究では鎮江上流お よび江陰の断面に関する資料が入手できた (図-1参照). 江陰については7年分の断面形状が記述されている。こ のうち2005年3月について断面形状を目視で読んだとこ ろ図-12のようになった。このことから，計算に用いる 横断面形を台形とし, 台形内の横断勾配は図-12より1/50 とした. 次に, 1次元河道モデルを作成するために，内 江で観測された水位観測值と仮想河道モデルで計算さ れた水位值を比較して, モデル作成に必要なパラメータ (水深, 河床勾配, 粗度係数, 拡散係数) の調節を行う.

データの比較はまず2003年について行い，パラメータ の初期值は前節で求めた推定值を利用した. 図-13には初 期值を利用した場合の結果と各パラメータを変更した場 合の一例を示寸．ここで，初期值の場合には計算值と観 測值の水位の振幅は同程度であるが，両者の位相がずれ ていることがわかる，そこで，各パラメータを系統的に 僅かに変化させて, 両者がほぼ合致するように調節を行 った．振幅と位相が全体的にほぼ合致しているため, こ の結果から河道モデルのパラメータを決定した.

次に2001年と2004年の水位に対して再現計算を行った ところ, 2003年の場合と同じパラメータでも, 図-13と同 程度に一致することがわかった。ここでは紙面の制約の ために, 2004年についての結果の一部を図-14に示寸. 以

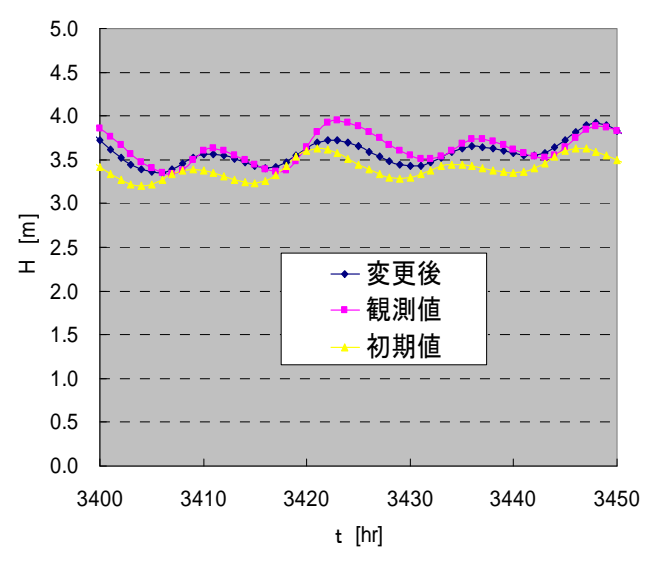

図-13 内江の水位（2003年の観測値と計算値）

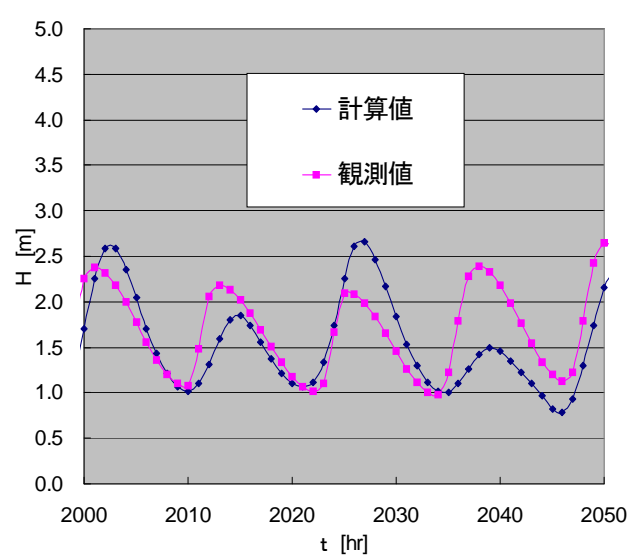

図-14 内江の水位（2004年の観測値と計算値）

上から，潮汐波の遡上に伴う内江付近の流量と水位の変 動が，本モデルにより概初再現できているものと考えら れ, 内江の水交換に関する準三次元計算の境界条件の推 定に用いることとした.

\section{6. おわりに}

本報では中国鎮江市内江における準3次元計算を行な うために，少ない現地観測データから計算に必要な境界 条件の導出を試みた. その結果, 合理的に境界条件を導 出することが出来た．頁の都合により結果は提示できな かったが,導出した条件を用いて準3次元計算を行った結 果, 内江での流動状況が潮汐の影響により大きい変化を することを確認した.

\section{参考文献}

1) 中国科学研究院地理研究所: 長江中下流河道特性及其演変, 1985.

2) 榊原進: ウェーブレットビギナーズガイド, 東京電機大学出 版局, 1995.

3) 水理公式集・例題プログラム集, 例題5-5, 土木学会, 2001. 